Hughes, J.R., Gust, S. W., KeENAN, R. M. et al (1989) Nicotine vs placebo gum in general practice. Journal of the American Medical Association, 261, 1300-1305.

,,--- et al (1990) Effect of dose on nicotine's reinforcing, withdrawat-suppression and self-reported efiects. Journal of Pharmacology and Experimental Therapeutics (in press).

\section{Phototherapy, winter depression and ocular pressure}

SIR: There is evidence to suggest that in depression, homeostatic regulatory mechanisms are more erratic and/or less responsive to incoming stimuli (Siever \& Davis, 1985). We have recently proposed that among many putative systems, ocular pressure dynamics may also be poorly regulated in at least a subgroup of seasonally depressed patients. It has been thus reported that patients with seasonal affective disorder (SAD) may, in the late afternoon, have significantly lower intraocular pressure (IOP) when compared with age- and sex-matched controls (Stojek \& Bilikiewicz, 1988). We have also shown (Stojek et al, 1990) that seasonally depressed women have a substantial reduction in rate of secretion of the aqueous fluid.

We now wish to report the results from tonometric and tonographic examinations performed between 9.00 a.m. and 10.00 a.m. in ten SAD women, before and after three days' treatment with bright ( 2500 lux) light for two hours twice a day (6.00 to 8.00, a.m. and p.m.). All the patients met DSM-III criteria for a major depression that developed during the fall or winter and remitted the following spring, for at least three consecutive years. Patients were entered into the study if they had, (1) a score of 16 or more on the 21-item Hamilton Rating Scale for Depression (HRSD), and (2) if their current history of winter depression was characterised by morning oversleeping. They all gave written informed consent to participate in the study. Studies were made from January through to December during the luteal phase of the menstrual cycle, to avoid a possible variation in IOP within this cycle. The ocular examinations were normal, and most of the eyes were emmetropic. Applanation tonometry with a plunger load of $5.5 \mathrm{~g}$ was performed on both eyes and the results were then averaged. The tonographic study was made on the right eye only. Facility of outflow (C) and rate of flow (F) were calculated according to Becker \& Schaffer (1961), and the episceral venous pressure of $8 \mathrm{mmHg}$ was used for these calculations. Data were analysed by paired $t$-test.

Bright light had a marked antidepressant effect (HDRS decreased from 23.6 to 5.9, $P<0.01$ ), and this was accompanied by a vivid reduction of the morning hypersomnia. The tonometric and tonographic studies revealed that after phototherapy, the mean (s.d.) IOP increased from 12.3(1.7) to $14.2(1.1) \mathrm{mmHg}(P<0.01)$. Likewise, the mean (s.d.) $\mathrm{F}$ before and after treatment increased from $1.18(0.47)$ to $3.2(0.98) \mathrm{c} \mathrm{mm} / \mathrm{min}$, respectively $(P<0.01)$, and the $C$ value increased from $0.21(0.04)$ to $0.34(0.11) \mathrm{c} \mathrm{mm} / \mathrm{min}$, respectively $(P<0.01)$. Both IOP and $F$ values increased most significantly in those two patients who were still given a moderate dose of tricyclic antidepressants.

While caution is warranted in interpreting data from only 10 patients, these findings, if considered in conjunction with previous work, suggest that phototherapy may improve the winter depression and attenuate the morning oversleeping parallel with increases in the amplitude of ocular pressure dynamics, and that the important factor might be the relative rates at which production of fluid and its elimination take place. Thus, an increased blood supply to the epithelial cells might be a critical factor in determining the availability of fluid and solutes into the eye during the light treatment. Some authors have theorised that increased IOP results from vascular changes in the eye that are irritated by the prolonged darkness and cold temperature of winter (Blumenthal et al, 1970). Since light per se increases the flow of clear fluid in normal eyes, but could sometimes have the opposite effect (Saeteren, 1960), it would thus be interesting to know whether the latter possibility might account for a wellknown phenomenon of supersensitivity to light in, at least, the SAD patients.

ANDRZej Stojek BOZENA KASPRZAK

Department of Psychiatry ADAM BILIKIEWICZ

School of Medicine in Gdansk

80-282 Gdansk-Wrzeszcz

1 Srebriniki St, Poland

\section{References}

BeCKER, B. \& SCHAFrer, R. (1961) Diagnosis and Therapy of Glaucoma. St Louis: Mosby Co.

Blumenthal, M., Blumenthal, R., Peritz, E. el al (1970) Seasonal variation in intraocular pressure. American Journal of Ophthalmology, 69, 608-610.

SAETEREN, T. (1960) Scleral rigidity in normal human eyes. Acta Ophtalmologica, 38, 303-311.

SteVER, L. J. \& DAvis, K. L. (1985) Overview: toward a dysregulation hypothesis of depression. American Journal of Psychiatry, 142, 1017-1031

Storex, A. \& Biunkiewicz, A. (1988) Bright artificial light lowers intraocular pressure and plasma sodium concentration less in depressed patients than healthy controls. Plinensky Lekarsky Sbornik, 56, 157-160.

Stojex, A., Kasprzak, B. \& Bulniewicz, A. (1990) Changes in ocular humor dynamics in SAD patients after phototherapy. Paper accepted for presentation at the 18th European Conference on Psychosomatic Research, 13-17 August 1990, Helsinki, Finland. 